\title{
Access to the Discount Window for All Commercial Banks: Is It Important for Monetary Policy?
}

\author{
R. ALTON GILBERT
}

$\mathbf{P}$ more banks to be members of the Federal Reserve System often argue that the existence of nonmember commercial banks creates problems for the conduct of monetary policy. Two of the most frequently mentioned of these problems are: First, the ratio of net demand deposits to bank reserves may become more variable as nonmember banks have a larger share of demand deposit liabilities. ${ }^{1}$ Second, as banks withdraw from membership, the average ratio of net demand deposits to reserves rises. With a lower average reserve base, fluctuations in reserves due to such factors as changes in float and currency holdings of the public make net demand deposits more variable. ${ }^{2}$ These potential problems have been subjected to extensive theoretical analysis.

Recently, a third possible problem with declining membership has been suggested - the fact that nonmember banks do not have access to the discount window on a day-to-day basis. Lack of direct access to the discount window for all commercial banks, it has been alleged, may preclude the adoption of appropriate monetary policy because of the Federal Reserve's concern about the differential impacts of these policies on member and nonmember banks. During periods of tight monetary policy, for example, declin-

${ }^{1}$ Dennis R. Starleaf, "Nonmember Banks and Monetary Control," Joumal of Finance (September 1975), pp. 955-75; and Kemneth J. Kopecky, "Nonmember Banks and Empirical Measures of the Variability of Reserves and Money: A Theoretical Analysis" Journal of Finance (March 1978), pp. 311 . 18.

2See, for example, J. A. Cacy, "Reserve Requirements and Monetary Control," Federal Reserve Bank of Kansas City Monthy Review (May 1976), pp, $3+13$. ing Federal Reserve membership might increase the liquidity risk for the entire banking system, since fewer banks would be able to use the discount window to provide a temporary offset to unexpected reserve outflows. ${ }^{3}$

The validity of this argument hinges on whether credit from the discount window significantly would help nonmember banks adjust to deposit withdrawals. Under existing legislation, the Federal Reserve has the authority to lend to nonmember banks in unusual emergencies in which these banks would fail without additional reserves. ${ }^{4}$ Increasing the number of banks that are members, therefore, would not increase the ability of the Federal Reserve to respond to such emergency situations.

"G. William Miller, "Statement," Monetary Control and the Membership Problem, U.S. Congress, House, Committee on Banking, Finance, and Urban Aftairs, 95th Congress, 2nd Session, July 27,1978 , pp. $60-62$; and statements by Sen. William Proxmire and Paul Volcker, Chaiman of the Federal Reserve Board, before the U.S. Senate Committee on Banking, Housing, and Urban Affairs, February 4, 1980.

${ }^{4}$ Credit from Fecteral Reserve Banks is classified as reserve adjustment credit, seasonal credit, and emergency credit. Adjustment credit is available for member banks to meet unexpected temporary credit denands caused by sudden deposit withdrawals or unanticipated loan demand. Seasonal credit is available to relatively small member banks that have seasonal patterns in their deposits and loans. Emergency credit may be made available to member or nonmember banks with severe financial difficulties. For additional information on the conditions under which the Federal Reserve makes credit available to banks, see R. Alton Gilbert, "Benefits of Borrowing from the Federal Reserve when the Discount Rate is Below Market Interest Rates," this Review (March 1979), pp. 25 32. This paper analyzes use of adjustment credit by member banks. For an analysis of seasonal borrowing, see Stanley L. Graham, "Is the Fed's Seasonal Borrowing Privilege Justified?" Federal Reserve Bank of Minneapolis Quarterly Review (Fall 1979), pp. 9-14. 
The type of monetary policy that the Federal Reserve may be precluded from adopting out of concerm for liquidity pressures on nonmember banks is presumably not that designed to create liquidity emergencies for the banking system. Concern that declining membership would increase liquidity risk to the banking system suggests, rather, that nonmember banks have greater difficulty than member banks in adjusting to unanticipated deposit withdrawals or changes in demands for credit in more normal circumstances than those emergencies in which the Federal Reserve would make credit available to nonmember banks. Since monetary policymakers are justifiably concerned about possible influences of Federal Reserve membership on the conduct of monetary policy, it is important to clarify whether lack of direct access to the discount window for nonmember banks does, indeed, pose a serious problem for monetary policy.

This article takes an indirect approach to determining whether nonmember banks have greater reserve management difficulties due to lack of access to the discount window. If borrowing from the discount window is a useful way to adjust to unanticipated reserve outflows, member banks would borrow from the discount window on at least a few occasions each year, taking advantage of their regular, reliable, dayto-day access to the discount window to meet unexpected withdrawals or to cushion themselves against temporary liquidity pressures. If, however, most member banks manage their reserve positions without borrowing at the discount window, it is doubtful that nonmember banks have significantly greater difficulty than members in responding to similar reserve outflows. In this case, lack of access to the discount window for nonmember banks is simply irrelevant to the membership issue.

\section{DO MEMBER TANS PORPOW

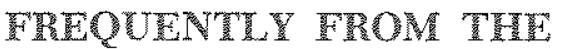 DISCOUNT WTIDOW?}

Most member banks do not borrow from the discount window; those few that do so generally borrow infrequently. From 1974 to 1977 , the proportion of the 430 member banks in the Eighth District that borrowed in any one year was as high as 25 percent only in 1974, when the discount rate was substantially below alternative short-term interest rates, ${ }^{5}$ of the 115 member banks that borrowed during 1974, only 21

${ }^{5}$ For further discussion of member bank borrowing, see Gilbert, "Benefits of Borrowing from the Federal Reserve." did so on more than 10 occasions, and only 55 borrowed five or more times (table 1). During 1975, only nine banks borrowed five times or more, and in 1976 only 10 banks borrowed that frequently.

The infrequent borrowing of member banks from the Federal Reserve indicates that, in most circumstances, they adjust to reserve losses without resort to the discount window. This is sufficient evidence for rejecting the view that nonmember banks necessarily have greater problems than member banks in coping with reserve outflows because they lack direct access to the discount window. If borrowing from the discount window were an important means for banks to adjust their reserve positions to reserve outflows, most member banks would borrow from the discount window. ${ }^{*}$ Yet, they do not do so.

\section{HOW DO MENBER BANKS ADUST TO PESERVE DPAISS?}

Most member banks manage their reserve positions by means other than borrowing at the discount window. This has implications for the significance of the discount window for the banking system's operation.

\section{Effects of Deposit Fluctuations on the Reserve Postitions of Member Banks}

Cash management by member banks is investigated by considering the factors that determine their desired cash holdings, the types of events that cause their cash holdings to be different from desired levels,

Although Reserve Banks classify borrowing by member banks as reserve adjustment or seasonal credit, it is often difficult to distinguish the purpose of borrowing in actual practice. Member banks that have the privilege of receiving seasonal credit often change the anount of seasonal credit they borrow daily or weekly. Use of the discount window for reserve adjustment is gauged in this article by the number of occasions on which a bank borrows from the discount window during a year, measured as the number of times when borrowing is positive followed by periods when borrowing is zero. Member banks that use the discount window for reserve adjustment on a routine basis tend to borrow on several occasions each year.

TThis conclusion is reinforced by noting that Fed reserve requirements are binding for most member banks, in the sense that they hold larger cash balances than they would in the absence of Fed reserve requirements, whereas state reserve requirements are not binding for most nonmember banks. In most states, required cash reserves of nonmember banks are substantially smaller than the cash reserves nonmember banks actually hold. See R. Alton Gilbert, "Effectiveness of State Reserve Requirements," this Review (September 1978), pp. 1628 . If most member banks do not borrow at the discount window to offset reserve drains in order to meet binding reserve requirements, nonmember banks would be even less likely to borrow at the discount window, if made available to them, unless they were made subject to member bank reserve requirements. 


\section{Table 1}

\section{Frequency of Borrowing from the Federal Reserve by Member Banks}

\begin{tabular}{|c|c|c|c|c|c|c|c|}
\hline \multirow{2}{*}{$\begin{array}{l}\text { Bank size } \\
\text { (Total deposits in } \\
\text { millions of dollars) }\end{array}$} & \multicolumn{6}{|c|}{$\begin{array}{l}\text { Number of Elghth District member banks that borrowed } \\
\text { on the following number of occasions each year }\end{array}$} & \multirow{2}{*}{$\begin{array}{l}\text { Total } \\
\text { number } \\
\text { of banks } \\
\text { borrowing }\end{array}$} \\
\hline & 1 & $2-4$ & $5-10$ & $11-15$ & $16-20$ & over 20 & \\
\hline \multicolumn{8}{|l|}{ mingers of } \\
\hline$\$ 0 . \$ 10$ & 7 & 8 & 7 & 8 & 0 & 0 & 30 \\
\hline $10-25$ & 14 & 21 & 8 & 0 & 1 & 0 & 44 \\
\hline $25-50$ & 3 & 2 & 11 & 2 & 0 & 0 & 18 \\
\hline $50-100$ & 2 & 1 & 4 & 1 & 0 & 1 & 9 \\
\hline over 100 & 1 & 1 & 4 & 2 & 3 & 3 & 14 \\
\hline \multicolumn{8}{|c|}{1975} \\
\hline$\$ 0-\$ 10$ & 2 & 2 & 1 & 0 & 1 & 0 & 6 \\
\hline $10-25$ & 2 & 8 & 1 & 1 & 0 & 0 & 12 \\
\hline $25-50$ & 6 & 4 & 1 & 1 & 0 & 0 & 12 \\
\hline $50-100$ & 3 & 2 & 0 & 0 & 1 & 0 & 6 \\
\hline Over 100 & 4 & 2 & 0 & 2 & 0 & 0 & 8 \\
\hline & & \multirow{2}{*}{\multicolumn{5}{|c|}{1976}} & \\
\hline $80-810$ & 2 & 2 & 1 & 1 & & 0 & \\
\hline $10-{ }_{25}$ & 4 & 0 & 1 & 1 & 0 & 0 & 6 \\
\hline${ }_{25}-{ }_{50}$ & 2 & 3 & 6 & 0 & 0 & 0 & 10 \\
\hline $50-100$ & 1 & 8 & 0 & 0 & 0 & 0. & $\begin{array}{r}10 \\
3\end{array}$ \\
\hline $\begin{array}{l}50-100 \\
\text { Over } 100\end{array}$ & 4 & 4 & 0 & 0 & 1 & $\begin{array}{l}0 \\
0\end{array}$ & 3 \\
\hline & 4 & 4 & & & 0 & 0 & 8 \\
\hline \multicolumn{8}{|c|}{1977} \\
\hline$\$ 0-\$ 10$ & 1 & 5 & 1 & 0 & 0 & 1. & 8 \\
\hline $10-25$ & 3 & 4 & 4 & 0 & 1 & 0 & 12 \\
\hline $25, \quad 50$ & 6 & 6 & 3 & 3 & 0 & 0 & 17 \\
\hline 50,100 & 2 & 4 & 2 & 0 & 0 & 0 & 8 \\
\hline over 100 & 2 & 5 & 7 & 3 & 1 & 0 & 18 \\
\hline
\end{tabular}

and their response to deviations of actual from desired cash balances. Cash balances of member banks can be classified into three components: vault cash, reserve balances at Federal Reserve Banks, and demand balances due from correspondents.

The amount of vault cash banks desire to hold is based upon their expectations of depositors" demand for currency. Reserve balances held by most member banks at the Federal Reserve are determined by their required reserve balances, which are based upon their deposit liabilities and vault cash held two weeks earlier. Required reserve balances change each week, and member banks must meet their required reserves on a weekly average basis. Finally, demand balances of member banks due from correspondents are determined by both the volume of transactions through those accounts and the balances their correspondents require as compensation for services provided. Correspondent banks generally do not charge respondents explicit fees for services; they require, instead, that respondents hold certain average demand balances with them. ${ }^{8}$

The primary cause of deviation between a bank's actual and desired cash balances is unanticipated fluctuation in demand deposit liabilities. Time deposits mature on specific dates, and therefore bank management can anticipate when it must be ready to

sRobert E. Knight, “Correspondent Banking Part III: Account Analysis," Federal Reserve Bank of Kansas City Monthly Review (December 1971), pp. 3-17. 
make payments to holders of time deposits. Demand deposit liabilities, however, fluctuate more from day to day and are, therefore, more difficult to estimate.

The effects of unanticipated Ioan demand on banks' reserve positions are reflected in changes in their demand deposit liabilities. When banks make loans, they increase the demand deposit balances of borrowers. If borrowers did not withdraw those deposits to make payments, there would be no disturbance in the current week to the reserve positions of banks making loans. Increases in loans cause banks to lose reserves only when borrowers withdraw deposits.

Bank customers withdraw deposits from their demand accounts either by demanding currency or by writing checks. When depositors demand currency, a bank's assets (vault cash) and liabilities (demand deposits) decrease simultaneously. Member banks lose reserves when depositors demand currency, but due to lagged reserve accounting, this decline in vault cash does not affect reserves available to meet reserve requirements in the current week. Likewise, the decline in demand deposit liabilities that results when depositors demand currency does not affect required reserves in the current settlement week, but two weeks later instead." Therefore, member banks may choose to make no initial response to a loss of reserves in the form of vault cash, unless total vault cash falls below some critical level at which the risks of temporary currency shortages become sufficiently great.

When customers withdraw demand deposits by writing checks, the effect on a member bank's cash assets depends upon how the bank clears checks and how it pays for checks drawn on its customers' accounts. Banks receive checks as their customers make deposits and, therefore, need a mechanism for collecting checks drawn on other banks. Some member banks receive payment for checks by having their reserve balance at their Reserve Bank credited, while paying for checks drawn on their depositors" accounts by having their reserve balances debited. Frequent debits and credits to member banks' reserve accounts cause these balances to change on most business days.

\footnotetext{
${ }^{9}$ Required reserves of a member bank in the ctirrent settlenent week are based upon its deposit liabilities two weeks earlier. The reserves that count toward meeting a member bank's required reserves in the current settlement week are average daily vault cash held two weeks earlier and average daily reserve balances at the Fed in the current week. For a comparison of how contemporaneous and lagged reserve accounting affects the reserve management of member banks, see $R$. Alton Gilbert, "The Effects of Lagged Reserve Requirements on the Reserve Adjustment Pressure on Banks," Financial Analysts Joumal (September-October 1973), pp. 34-43.
}

If a member bank clears checks through its reserve account, net withdrawals of deposit liabilities cause its reserve balance to decline. Required reserves for the current week, however, are not affected by deposit withdrawals in the current week due to lagged reserve requirements. Thus, if its initial reserve balance just equaled its required balance for the current week, deposit withdrawals during the week would cause a member bank's reserve balance to be deficient. Borrowing through the discount window is one means of increasing reserves on short notice.

Other member banks clear checks through their balances at correspondents. They deposit checks with their correspondents and pay for checks drawn on depositors' accounts by having their demand balances due from correspondents debited, including checks presented for payment by the Federal Reserve. If these banks do not use other Reserve Bank services that cause their reserve balances to change, these balances would change only when banks adjusted them to equal their required reserve balances. ${ }^{10}$ Thus, the reserve balances of member banks that use services of correspondents tend to change less frequently than those of member banks that make greater use of Reserve Bank services.

For a member bank that clears checks through a correspondent bank, net withdrawals of deposit liabilities would not disrupt its balance between actual and required reserves for the current week. The decline in demand deposit liabilities instead would affect the bank's required reserves in coming weeks. Since checks are cleared through the bank's correspondent account, its reserve balance is unaffected by net deposit withdrawals.

The response of these member banks to deposit withdrawals depends upon the constraints placed on them by their correspondents. If respondent banks were required to hold certain minimum amounts of demand balances at correspondents on a weekly average basis, they occasionally would have to obtain additional cash balances when experiencing net withdrawals of deposit liabilities. Studies of correspondent banking, however, indicate that respondent banks may average their balances over longer periods of time, such as a quarter or even a year, in meeting the balance requirements of correspondents. ${ }^{11}$ Respondent

\footnotetext{
10Use of the following Reserve Bank services may involve debits and credits to reserve balances: wire transfers, coin and currency shipments, and collection of coupons on securities held in safekeeping and matured securities.

11Kuight, "Correspondent Banking."
} 
banks may have enough flexibility in managing their cash positions to simply let their demand balances due from correspondents fluctuate as their deposit liabilities fluctuate with no additional response to deposit outflows.

One method of determining whether respondent banks may temporarily reduce their demand balances due from correspondents by amounts equal to shortterm deposit outflows is to compare the dollar magnitude of changes in demand deposit liabilities to changes in their demand balances due from correspondents. When large decreases in demand balances due from correspondents were compared to large decreases in gross demand deposit liabilities for 95 member banks that obtain most of their services through correspondents, the ratio of the former to the latter averaged 1.04. ${ }^{2}$ Thus, large weekly decreases in demand balances due from correspondents are of approximately the same dollar magnitude as large weekly decreases in gross demand deposits. These results indicate that respondents have enough shortterm flexibility in managing their cash positions that they can cope with relatively large decreases in their gross demand deposit liabilities by letting their demand balances due from correspondents decline temporarily.

\section{Are Demand Deposit Withdrawals Large Enough to Induce Banks to Borrow?}

Only those member banks that clear checks through their reserve accounts have reductions in their re-

\footnotetext{
12The 95 member banks, located in the Eighth District portions of Illinois and Missotri, had total deposits of less than $\$ 50$ million in 1976. None of these banks cleared checks through the Reserve Bank regularly. These banks had so little activity in their reserve balances at the Fed that the dollar amounts in their reserve balances remained unchanged for 150 days or more during 1976. Relatively large declines in the demand deposit liabilities at individual banks are measured by calculating the changes in gross demand deposits from each reserve settlement week to the next and determining the fifth largest decline. That amount is compared to the fifth largest weekly decline in demand balances due from correspondents, a measure of relatively large weekly decines in balances due from correspondents. An alternative comparison would be of the greatest weekly decline in demand deposit liabilities to the greatest weekly decline in demand balances due from correspondents. Such comparisons were not reported because, for many banks, the greatest weekly declines were substantially different from declines in other weeks and, therefore, not representative of the relatively large weekly declines in these series. Examination of weekly declines in both series indicated that the fifth greatest weekly declines tend to be fairly representative of large declines. For instance, the third greatest weekly decline in denand balances due from correspondents divided by the third greatest decline in gross demand deposits averages 1.06 .
}

serve balances when experiencing net demand deposit outflows. These are the banks, therefore, that tend to borrow frequently from the discount window. Even for those banks that use their reserve balances for clearing checks, however, fluctuations in demand deposit liabilities may not be large enough to induce them to borrow to avoid reserve deficiencies. If fluctuations in their reserve balances are smaller than their normal excess reserves, no response to declines in demand deposit liabilities is necessary.

This issue is investigated by comparing average excess reserves to large decreases in demand deposit liabilities for a group of 1.02 member banks that make extensive use of Reserve Bank services. ${ }^{13}$ The fifth largest weekly decrease in gross demand deposits was larger than their average excess reserves in 1976 for all but one of these banks. Those relatively large decreases in deposits were, on the average, about 60 times larger than average excess reserves. ${ }^{14}$ Therefore, excess reserves could not fluctuate by as much as demand deposits during at least several weeks each year. When demand deposit liabilities decline by relatively large amounts, member banks that clear checks through their reserve accounts must obtain additional reserves to avoid reserve deficiencies.

\section{Do Frequent Borrowers Clear Checks Through Their Reserve Accounts?}

The next step is to determine whether member banks that borrow from the discount window most frequently are, in fact, primarily among those banks that clear checks through their reserve accounts. A reliable indicator of whether a member bank uses its reserve balance for settlement in check collection is the frequency of changes in its reserve balance from day to day. Check collection is the only Reserve Bank

\footnotetext{
13The reserve balances of these member banks were unchanged on no more than five business days during 1976.

14The ratio of the fifth largest weekly decline in gross demand deposits to average excess reserves was higher for larger banks, as indicated in the following display:

Size troup

Total deposits, in minhois

of dollats)

$\$ 0-\$ 10$

$10-25$

25 - 50

$50-100$

100 and over

Sum of the fifth largest Number
of of
banks $\quad$\begin{tabular}{c} 
sum of avezage excess reserves \\
\hline
\end{tabular} 7 4.46 10.02 84.88 83.16 92.50
} 


\section{Table 2}

\section{Comparison of the Frequency of Changes in Reserve Balances of Frequent Borrowers and Other Member Banks}

\begin{tabular}{|c|c|c|c|c|c|c|c|c|c|c|c|}
\hline \multirow{2}{*}{$\begin{array}{l}\text { Size category } \\
\text { (Annual average } \\
\text { total deposits, } \\
\text { millions of dollars) }\end{array}$} & \multirow[b]{2}{*}{ Type of bank } & \multicolumn{10}{|c|}{$\begin{array}{l}\text { Distribution of banks by the measure of frequency } \\
\text { of change in reserve balances at the Fed (Number } \\
\text { of days during a year when a member banks reserve } \\
\text { balances at the Fed were the same as on the previous day) }\end{array}$} \\
\hline & & Up to & $116=$ & $\begin{array}{l}121- \\
130\end{array}$ & 131 & 151 & $\begin{array}{l}176 \\
200\end{array}$ & 201 & $\begin{array}{l}251 \\
300\end{array}$ & $\begin{array}{l}301 \\
\text { \& Over }\end{array}$ & $\begin{array}{l}\text { Number } \\
\text { of banks }\end{array}$ \\
\hline \multirow[t]{6}{*}{$\$ 0-\$ 10$} & Infrequent borrowers & 3 & 2 & 4 & 3 & 3 & 5 & 18 & 8 & 7 & 53 \\
\hline & Frequent borrowers in & & & & & & & & & & \\
\hline & 1974 & 5 & 3 & 1 & 2 & & 1 & 1 & 2 & & 15 \\
\hline & 1975 & 2 & & & & & & & & & 2 \\
\hline & 1976 & 1 & & & & & 1 & & & & 2 \\
\hline & 1977 & 1 & & & 1 & & & & & & 2 \\
\hline \multirow[t]{6}{*}{$\$ 10-\$ 25$} & Infrequent borrowers & 17 & 7 & 9 & 8 & 10 & 5 & 14 & 10 & 2 & 82 \\
\hline & Frequent borrowers in & & & & & & & & & & \\
\hline & 1974 & 7 & & & 1 & 1 & & & & & 9 \\
\hline & 1975 & 2 & & & & & & & & & 2 \\
\hline & 1976 & 2 & & & & & & & & & 2 \\
\hline & 1977 & 5 & & & & & & & & & 5 \\
\hline \multirow[t]{6}{*}{$\$ 25-\$ 50$} & Infrequent borrowers & 15 & 5 & 5 & 4 & 5 & 3 & 1 & & & 38 \\
\hline & Frequent borrowers in & & & & & & & & & & \\
\hline & 1974 & 12 & & & & 1 & & & & & 13 \\
\hline & 1975 & 2 & & & & $\because$ & & & & & 2 \\
\hline & 1976 & 4 & & & 1 & & & & & & 5 \\
\hline & 1977 & 6 & & & & & & & & & 6 \\
\hline \multirow[t]{6}{*}{$\$ 5-\$ 100$} & Infrequent borrowers & 11 & 2 & & 1 & 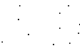 & & & & & 14 \\
\hline & Frequent borrowers in: & & & & & & & & & & \\
\hline & 1974 & 6 & & & & & & : & & & 6 \\
\hline & 1975 & 1 & & & & & & & & & 1 \\
\hline & 1976 & 1 & & & & & & & & & 1 \\
\hline & 1977 & 2 & & & & & . & & & & 2 \\
\hline \multirow[t]{6}{*}{ Over $\$ 100$} & Infrequent borrowers & 0 & & & & & & & & & 0 \\
\hline & Frequent borrowers in: & & & & & & & & & & \\
\hline & 1974 & 12 & & & & & & & & & 12 \\
\hline & 1975 & 2 & & & & & & & & & 2 \\
\hline & 1976 & 0 & & & & & & & & & 0 \\
\hline & 1977 & 11 & & & & & & & & & 11 \\
\hline
\end{tabular}

1Banks designated as frequent borrowers are all Eighth District member banks that borrowed at the discount window on five or more occasions during a year. Those designated as infrequent borrowers are member banks in the Eighth District portions of Illinois and Missour that did not borrow at the discount window in 1976 and were not frequent borrowers during 1974 , 1975 , or 1977 . 
service that is likely to cause a member bank's reserve balance to change each business day ${ }^{16}$

The distribution of nonborrowers and frequent borrowers by activity in their reserve balances is presented in table 2. Almost all of the Eighth District member banks that borrowed on five or more occasions per year in 1975-77 had changes in their reserve balances on each business day. Incentive to borrow from the discount window was relatively great during 1974 due to the large spread between market interest rates and the discount rate. Several banks that borrowed frequently in 1974 had relatively idle reserve balances. More of the frequent borrowers during 1974 , however, had relatively active reserve balances than nonborrowers of comparable size. ${ }^{1 t}$ Thus, evidence in table 2 supports the hypothesis that banks which borrow frequently are primarily among those that have relatively active reserve balances.

\section{Why Are Only Some of the Member Banks with Active Reserve Balances Frequent Borrowers?}

Fluctuations in deposit liabilities at member banks that use correspondent services tend not to induce frequent, short-term borrowings from the discount window since those banks can adjust to decreases in deposit liabilities by letting their balances at correspondents decline temporarily. Thus, banks that use services of correspondents may not be induced to borrow from any source in response to relatively large withdrawals of deposit liabilities. But among member banks that clear checks through their reserve accounts, and consequently have frequent changes in their reserve balances, why do some bor-

\footnotetext{
${ }^{15}$ The relation between use of Fed services and frequency of changes in reserve balances can be illustrated for member banks in the Eighth District portions of Illinois and Missouri, based on a survey of utilization of Fed services during 1976-77. Frequency of change in reserve balances is measured over 126 calendar days from mid-September 1976 to mid-January 1977. The minimum number of days that a member bank's reserve balance would be unchanged during that period is 39 . For the 68 banks that deposited more than five checks to their reserve balances during January 1977, reserve balances were unchanged an average of 39.9 days. A contrasting group is composed of 69 banks that cleared no checks through the Fed and used the reserve balances of their correspondents in remitting for the Fed's cash letters and handling transactions with the Fed for coin and currency. Their reserve balances remained unchanged for an average of 75.6 days.

${ }^{16}$ Among member banks with total deposits up to $\$ 50$ million, about 65 percent of the banks that borrowed frequently in 1974 had reserve balances that remained unchanged for 115 days or less, whereas only 20 percent of nonborrowers had such active reserve balances.
}

row from the discount window frequently and others never do?

One possible answer is that, among member banks with relatively active reserve balances, the frequent borrowers have more highly variable deposit liabilities, and thus are induced to borrow from the discount window more frequently to replace reserves lost due to deposit withdrawals. Table 3 indicates that frequent borrowers in the years 1975-77 tend to have more highly variable demand deposit liabilities than other banks of comparable size with similar activity in their reserve balances. ${ }^{17}$

Another factor that might account for the difference in frequency of borrowing is the difference in ratios of loan to deposits. Banks with higher ratios of loan to deposits tend to have smaller amounts of liquid assets, which they can sell quickly to replace reserve drains. Frequent borrowers had significantly higher loan-to-deposit ratios in 1976; the difference was positive, but not statistically significant at the 5 percent level in 1977. Thus, there is some evidence that, among the relatively small member banks with active reserve balances, those that borrow frequently from the discount window have higher ratios of loans to deposits. ${ }^{18}$

Differences in federal funds positions might also explain the varied use of the discount window by banks with active reserve balances. Reserve balances can be increased either by borrowing from the discount window or by reducing federal funds sold to correspondents. Loans in the federal funds market

17The characteristics of member banks that borrowed from the discount window on five or more occasions in 1974 , but were not frequent borrowers in the following three years, were also compared to those of member banks with relatively active reserve balances that did not borrow frequently in any of the years 1974-1977. The banks that borrowed frequently only during 1974 did not have greater variability in their demand deposit liabilities than the other banks. They did have higher ratios of loans to deposits than nonborrowers. However, the banks that borrowed frequently only during 1974 had such large proportions of their assets invested in federal funds sold on average, and positive net federal funds sold so often, that they were not induced to borrow frequently from the discount window during the following years. Analysis in table 3 is limited to banks with total deposits up to $\$ 50$ million because there were only two frequent borrowers in 1975-77 with total deposits between $\$ 50$ million and $\$ 100$ million (average for 1976 ); including those two banks in the analysis, and making comparisons to nonborrowers with total deposits up to $\$ 100$ million might bias some of the comparisons in table 3 .

18 A study of Tenth District member banks found that banks which borrowed from the discount window had higher ratios of loans to assets than nonborrowers of comparable size. See J. A. Cacy, "Determinants of Member Bank Borrowing," Federal Reserve Bank of Kansas City Monthly Review (February 1971), pp. 11-20. 
Table 3

Comparison of Frequent Borrowers and Nonborrowers with Relatively Active Reserve Balances (1975-77)

\begin{tabular}{|c|c|c|c|c|}
\hline Measure & $\begin{array}{l}\text { Frequent } \\
\text { borrowers }\end{array}$ & Norborrowers? & Difference & T-statistic \\
\hline Variability of demand deposits 3 & $6,60 \%$ & $482 \%$ & $1,78 \%$ & 2.0260 \\
\hline \multicolumn{5}{|c|}{$\begin{array}{l}\text { Percentage of average loans to average } \\
\text { total deposits }\end{array}$} \\
\hline 1976 & $6181 \%$ & $54.18 \%$ & $763 \%$ & 22991 \\
\hline 1977 & 6371 & 58.52 & 5,19 & 15895 \\
\hline \multicolumn{5}{|c|}{$\begin{array}{l}\text { Number of weeks in which net feferal funds } \\
\text { sold was zero or negative }\end{array}$} \\
\hline 1976 & 20.44 & 7.98 & 12,46 & 3.5466 \\
\hline 1977 & 20.44 & 10.64 & 9.80 & 27838 \\
\hline \multicolumn{5}{|c|}{$\begin{array}{l}\text { Average percentage of net federal funds } \\
\text { sold to total deposits } 4\end{array}$} \\
\hline 1976 & $2.20 \%$ & $5.87 \%$ & $3,67 \%$ & -22940 \\
\hline 1977 & 2,32 & 5.41 & 3,09 & $-2,179$ \\
\hline Number of banks & 18 & 47 & & \\
\hline
\end{tabular}

1 Analysis is limited to banks with average tolal deposits in 1976 of less than 850 million dollars.

The reserve balanees of these banks were unchanged on no nore than 120 days during 1976.

V Variability of demand deposits is neasured in the following way $A$ bank $s$ demand deposit habilities as of each business day are compared with yerage demand deposit habilities in the five previous business days, and the percentage deviation of deposits of ead day from the fhe day noving average is caleulated. The standard deviation of those percentage differences (positive and negative signs retained) is calculated for each year as a measure of the day to day variability of a bank's demand deposit labilities, For interpretation of this measure, stppose a bank has a standard deviation of 5 percent, For that bank the percentage deviations of demand deposit balances from the five-day noving average would lie within a range 5 percentage points below and above the mean on about two-thirds of the days turing the year Measuring deposit variability with this standard deviation weights the measure toward the more extreme percentage deviations from the five-day moving averages, which is appropnate for a neasure that might be correlated with frecuency of borrowing by banks to avoid resenve defictencies.

4 Net federal funds sold are counted as zero for weeks no which banks purchased more federal funds than they sold.

generally have maturities of one day, and, therefore, banks that sell federal funds can increase their reserve balances quickly by reducing the amount of federal funds they sell. Federal Reserve regulations do not permit member banks to receive reserve adjustment credit through the discount window while selling federal funds. Infrequent borrowers with active reserve balances may sell federal funds so often that they are seldom permitted to borrow from the discount window.

Two aspects of federal funds positions are analyzed in table 3 . One is the number of weeks during each year in which a bank's net federal funds sold was zero or negative. A bank with positive net federal funds sold during most weeks tends to have few occasions on which it would be induced to borrow. The number of weeks during which net federal funds sold were zero or negative is significantly greater for frequent borrowers in both 1976 and 1977.

The other measure of federal funds position is average federal funds sold as a percentage of average total deposits, a measure of the cushion of liquidity a bank maintains in the form of federal funds sold. This percentage is significantly lower for frequent borrowers in both 1976 and 1977 .

Analysis of the characteristics of banks that borrow frequently from the discount window indicates that use of the discount window for reserve adjustment is a valuable service for frequent borrowers. Banks that borrow frequently are among those that make extensive use of Reserve Bank services. They tend to have greater short-term variability in their demand deposit liabilities and have higher 
ratios of loans to deposits. In addition, net federal funds sold, which are smaller on average and zero more often than for other banks, indicate that they substitute use of the discount window for holding liquid assets.

Most member banks, however, prefer to adjust their reserve positions to deposit fluctuations by methods other than borrowing at the discount window. Among relatively small member banks (those with total deposits less than $\$ 100$ million), most clear checks through correspondents. These banks can cope with deposit fluctuations by allowing their demand balances due from correspondents to fluctuate. Of the relatively small member banks that clear checks through their reserve balances, most prefer to adjust their reserve positions to deposit outflows by drawing system that resulted from, or were compounded Only a small minority of member banks borrow from the discount window as a method of reserve adjustment.

\section{SWALIMTY OF THE CORMESPNDENT BANTING STSTEM}

One of the reasons for creating the Federal Reserve System was concem over liquidity crises of the banking system that resulted from, or were compounded by, simultaneous demands for cash by respondent banks from their correspondents. This concern might still be relevant, given the continuing reliance of most banks on correspondents for liquid balances.

Percentage changes from week to week in demand balances of individual banks due from correspondents are often quite large. Does it follow that demand balances of correspondent banks due to respondents are also highly variable from week to week? Are correspondent banks vulnerable to liquidity problems as a result of large fluctuations in their demand balances due to respondent banks?

The variability of total demand balances due to respondents depends upon the size of the bank's total balances due to respondents (see table 4). For the three largest correspondent banks, total demand balances due to respondents are about as variable as total demand deposit liabilities due to private nonbank depositors. For smaller correspondent banks those balances are more variable than their other demand deposit liabilities. This contrast is greatest for the 21 smallest correspondent banks: The measures of variability in their demand deposit liabilities due to private nonbank depositors were about the same as for the larger correspondent banks, but bal-

\section{Table 4 \\ Variability of Demand Balances Due to Commercial Banks and Private Nonbank Depositors}

\begin{tabular}{|c|c|c|}
\hline $\begin{array}{l}\text { Annual average } \\
\text { of demand balances } \\
\text { due to respondents } \\
\text { (millions of dolfats) }\end{array}$ & $\begin{array}{l}\text { Measure of } \\
\qquad \text { balan } \\
\text { Commercial } \\
\text { banks }\end{array}$ & $\begin{array}{l}\text { ariability of demand } \\
\text { tces due to } \\
\text { Nonbank depositors } \\
\text { other than the } \\
\text { U. S. government }\end{array}$ \\
\hline \multicolumn{3}{|c|}{ (10 largest correspondent banks) } \\
\hline$\$ 162$ & $5.5 \%$ & $5.4 \%$ \\
\hline 141 & 7.3 & 5.7 \\
\hline 141 & 7.8 & 6.7 \\
\hline 91 & 6.1 & 3.7 \\
\hline 60 & 14.1 & 3.0 \\
\hline 59 & 10.6 & 3.8 \\
\hline 53 & 8.0 & 4.0 \\
\hline 35 & 9.8 & 7.1 \\
\hline 27 & 11.7 & 7.5 \\
\hline 8 & 120 & 3.5 \\
\hline \multicolumn{3}{|c|}{ (Averages tor 21 smaller correspondent banks) } \\
\hline$\$ 1.06$ & $30.3 \%$ & $5.1 \%$ \\
\hline \multicolumn{3}{|c|}{$\begin{array}{l}\text { These banks were selected from among all Eighth District } \\
\text { member banks that borrowed from the discount window } \\
\text { durmg } 1976 \text { and other Eighth District member banks } \\
\text { in Wlinois and Missouri, A bank is assumed to be offering } \\
\text { correspondent services to other banks if its demand bal- } \\
\text { ances due to respondents are positive each day and change } \\
\text { each business day. }\end{array}$} \\
\hline \multicolumn{3}{|c|}{$\begin{array}{l}\text { 2Variability of these balances is measured by calculating } \\
\text { average balances for each reserve settlement week in } 1976 \text {, } \\
\text { percentage changes in balances from each week to the } \\
\text { next, and then taking the standard deviation of the per- } \\
\text { centage changes. }\end{array}$} \\
\hline
\end{tabular}

ances due to respondents were substantially more variable. Their demand balances due to respondents were about as variable from week to week as demand balances due from correspondents of individual banks that clear checks through correspondents. For 95 member banks that obtain most of their services through correspondents, the average measure of weekly variability in their demand balances due from correspondents is 29.5 , which is approximately equal to the average measure of variability in demand balances due to respondents of 30.3 for the 21 smallest correspondent banks. ${ }^{19}$

10 Variability of demand balances of correspondents due to respondents is measured as the standard deviation of percentage changes in those balances from week to week. Variability of demand balances due from correspondents is measured the same way. The 95 member banks which use correspondent services are described in footnote 12 . 
These comparisons indicate that the relatively large correspondent banks have an advantage over smaller correspondents in coping with the variability in demand balances due to individual respondent banks. For correspondents that serve the largest number of respondent banks, fluctuations in balances due to individual respondent banks tend to cancel each other out, causing their total demand balances due to other banks to be no more variable from week to week than the sum of other demand deposit liabilities. Correspondents that serve fewer respondents do not benefit as much from such cancellation. Thus, the largest correspondent banks are able to offer respondents the service of reserve adjustment mechanisms with no more vulnerability to occasional liquidity problems resulting from fluctuations in their balances due to respondents than that from fluctuations in balances due to nonbank depositors.

\section{SUMMARY AND CONCLUSTONS}

It recently has been suggested that one adverse effect of declining Federal Reserve membership is that the Federal Reserve may become more reluctant to pursue restrictive monetary policy because of its uneven impact on the banking system. Nonmember banks, without access to the discount window, might not have the means to cope with liquidity pressures resulting from restrictive monetary policy. Therefore, extending access to the discount window to more banks, by inducing or requiring more banks to be members, would facilitate the implementation of monetary policy.

The validity of this argument is investigated by examining the frequency with which member banks borrow at the discount window. If access to the discount window helps banks adjust to occasional liquidity pressures, most member banks would borrow frequently from the discount window as a means of coping with such pressures. Only a small minority of member banks, however, actually borrows frequently from the Federal Reserve. Therefore, while there are valid reasons for suggesting that reductions in membership may interfere with monetary control, analysis of reserve management by banks does not indicate that direct access to the discount window for nonmember banks is important for the conduct of monetary policy.

Many member banks adjust to declines in their cash balances by letting their demand balances due from correspondents decline temporarily. This reaction is automatic for banks that clear checks through correspondent balances. For banks that clear checks through accounts at their Reserve Bank, net withdrawals of deposit liabilities cause reductions in their reserve balances, and may occasionally cause reserve deficiencies unless offset. Banks that borrow frequently at the discount window are among these banks that clear checks through their reserve accounts. Most member banks that clear checks through reserve accounts, however, do not borrow frequently from the discount window, but instead rely upon federal funds sold to correspondents as a cushion of liquidity, reducing federal funds sold when experiencing reserve outflows.

The relatively large correspondent banks benefit from offsetting fluctuations in the deposits due to individual respondent banks. Thus, large correspondent banks can offer respondents means of adjusting their cash positions to deposit fluctuations without incurring any more variability in their own liabilities than results from fluctuations in demand balances due to nonbank customers. This indicates that correspondent banks offer member and nonmember banks adequate means of adjusting their cash position to fluctuations in deposit liabilities.

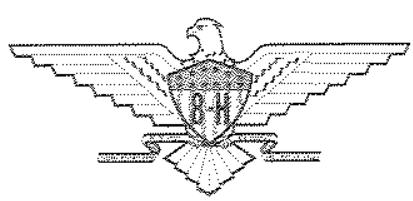

